International Journal of Indonesian Philosophy \& Theology

2020, Vol. 1(2): 105-115

(C) The Author(s) 2020

p-ISSN: 2722-8894; e-ISSN: 2722-8886

DOI: 10.47043/ijipth.v1i2.10

https://aafki-afti.org/ijipth

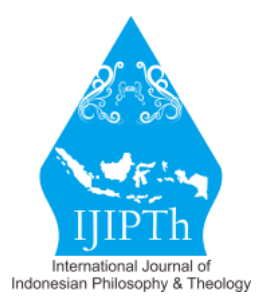

\title{
Doing Theology and Our Theological Education: An Indonesian Perspective
}

\author{
Raymundus I Made Sudhiarsa \\ Sekolah Tinggi Filsafat Teologi Widya Sasana, Malang, Indonesia \\ Email: derai2013@gmail.com
}

\begin{abstract}
The article argues that doing theology in multi-cultural and multi-religious society expects a close collaboration of multi-disciplines. Such an interdisciplinary approach makes theology possible to look at the people's problems in a comprehensive way. The church in Indonesia has been struggling quite a lot in this theological endeavor. The International Joint Conference held in Yogyakarta, Indonesia (March 2019), was an important event. And the response to the discussions at the conference attempts to deal with the importance of theology in context. And its impacts on theological educations in the country. The article then suggests that everyone revisit our traditional theological programs and make necessary revisions needed to respond to the contemporary world. In this way, the church could claim the relevance of its existence and its public theology for the country's goodness and the betterment of the society at large.
\end{abstract}

Keywords: doing theology, public theology, interdisciplinary approach, theological curriculum

\begin{abstract}
Abstrak: Paper ini berpandangan bahwa berteologi dalam konteks masyarakat multi-kultural dan multi-religius menegaskan kolaborasi multidisiplin. Pendekatan interdisipliner memungkinkan teologi mampu melihat problem masyarakat secara komprehensif. Gereja Indonesia telah dan sedang banyak berjuang di dalam upaya teologis ini. Konferensi Internasional di Yogyakarta (Maret 2019) merupakan salah satu cetusannya. Dalam rangka merespon diskusi dalam konferensi tersebut, paper ini membahas pentingnya berteologi dalam konteks dan imbasnya dalam pendidikan teologi di tanah air. Kami mengusulkan untuk melakukan revisitasi program-program tradisionalteologis dan membuat revisi-revisi yang diperluan untuk menanggapi dunia kontemporer. Dalam cara ini, Gereja Katolik Indonesia baru dapat menegaskan relevansi keberadaannya dan berteologi publik demi kebaikan tanah air dan perbaikan masyarakat luas pada umumnya.
\end{abstract}

Keywords: berteologi, teologi publik, pendekatan interdisipliner, kurikulum teologi

\section{Introduction}

We have honestly to acknowledge that there has been plenty of discussion on theology in context, worldwide, and at the regional or national level. The International Joint Conference held in Yogyakarta last year (2019) was one such promising event for the Church in Indonesia in general and faculties of theology. The theme of the conference was Doing Theology in Contemporary Indonesia: Interdisciplinary Perspectives. The conference's keynote speaker, Felix Wilfred, Emeritus Professor of the State University of Madras, India, presented his insightful observations on the paper entitled Asian Theological Ferment (Wilfred, 2019). As one of our Asian renowned theologians, Felix Wilfred is undoubtedly an undisputed resource person in this field of theological debate.

His presentation was (and is) surely of great inspiration and encouragement for the witnessing Church in Asia and theologians and the theological institutions in this continent - in my mind, I am primarily thinking of the Church in Indonesia. In his address, Wilfred highlighted three main contextual issues, viz. (1) a strong ferment of liberation sweeping across Asia in the post-colonial era; (2) the spirit 
of pluralism, inclusion, and integration of Asian theology; and (3) the move toward a new theological direction such as developing a public theology. In other words, the context, namely the concrete life experiences of Asians, constitutes a general point of reference for our societies' theological discourses.

Doing theology presupposes a close collaboration primarily with social sciences, such as sociology, anthropology, psychology, cultural and religious studies, and the like. Then, we are convinced that the life experiences of the people in Asian societies in dialogue with the Scriptural message and the rich Christian Tradition are the three important loci that construct our theological discourse (Bevans 2003, pp. 3-7). In my opinion, doing theology in our times and within our context will also affect our learning theology in our theological institutions. In other words, we are expected to revisit our theological curriculum and make a close and critical dialogue with, for example, the four traditional types of theology (biblical studies, church history, systematic theology, and practical theology).

This article was initially a response to Wilfred's paper at the conference. With some revision, it tries to actualize the response with the same intention, namely to support our theological educations in carrying out their mission in doing theology. It is in line with most Christians' desire (lay and clergy) to build up a theology of their own, an effort of self-theologizing (Hiebert, 1985). To some extent, this is the real meaning of 'being Church' or 'being a missional Church' (Ad Gentes no. 2). This enduring effort will be followed by a discussion on the way towards the church in its maturity. Maturity in dialogue with Indonesian soil and soul; within the plurality of context; what makes our theology authentic. And in conclusion, we wish to propose a plan on revisiting our theological curriculum in response to doing theology with interdisciplinary perspectives.

\section{An Enduring Debate}

As mentioned above, there has been plenty of discussion in the last few decades about the topic of doing theology in context. Despite that, people still consider that there is a lack of theological breakthrough as well as the so-called interdisciplinary approach. The topic is certainly of great importance for the church in presenting itself to the larger society, the church for the world, "a church which goes forth," as Pope Francis formulates it (Francis, 2013). To some extent, it has been an enduring debate at the national level and each theological institution's level across the country.

More than a decade ago, Jan Aritonang and Karel Steenbrink, for example, have tried to organize joint research on the development of Christian communities throughout the Indonesian archipelago. In collaboration with many observers, lectures, and researchers (Catholics and Protestants, men and women, missionaries and locals, trained theologians and common Christians), the two scholars planned to produce a so-called theology from below and to fill in the gap of 'historical lacuna'. It is quite true, for in the last quarter of the 20th century there was not a comprehensive publication with regard to Christianity that covers the history of both sides (Catholicism and Protestantism). They also assumed that the people's role or the laity had been underestimated in the history of Christianity. It occurred not only in Indonesia but also elsewhere throughout the globe. They managed then to treat people as subjects of faith or agents of a 'living-theology.' As an outcome, a mammoth book of 1004 pages appeared to the public in 2008 (Aritonang and Steenbrink, 2008). The book was arranged to balance similar books on the history of Christianity, which always put missionaries or leaders of the communities as the primary agents of faith and of building up Christian communities (Muskens, 1979; Rosarianto, 2001).

We also have to highly appreciate the many publications made by individual theologians and corporate researchers on the local and national issues, since the first encounter of Christian message and 
the Indonesian soil in the 7th Century in Pansur (now Barus on the west coast of North Sumatra) to present-day Indonesia (Aritonang and Steenbrink, 2008, p. 5). We are convinced that our philosophical and theological institutions across the country have published several books, journals, chronicles, newsletters, letters, biographies, personal documents, and the like that count the story of our Christianity on Indonesian soil. Such various reflections, analyses, and narratives have been considered as essential parts of the three volumes of Asian Christian Theologies (2002, 2003, 2004) of Asian Theologians (England et al., II, 2004).

The issue of doing theology in the Indonesian context has been of an exciting debate as well. Its inception might be started when the idea of training and educating the future Indonesian priests came to the fore. It came up to church's awareness by November 1911, followed by seminaries' foundation across the country. The first two minor seminaries were founded di Java (St. Peter Canisius Minor Seminary, Mertoyudan, May 20, 1912) and Flores (St. John Berchmans Minor Seminary, Mataloko, September 15, 1929). At the same time, the first two major seminaries were founded in Java (St. Paul Major Seminary, Kentungan, Yogyakarta, August 15, 1936) and in Flores (St. Paul Major Seminary, Ledalero, May 30, 1937).

Concerning typologies or models of doing theology, let us mention a few. First, there is a model where western forms of theology take the local or national garments. The examples for this model are mostly in the form of manuscripts. Such as theological materials for class discussions or lectures. We can also mention, for example, the books such as Iman Kristen (Christian Faith) of Harun Hadiwijono (1992), Pokok-pokok Penting Iman Dari Kristen (Essentials of Christian Faith) of J.L.Ch. Abineno (1989), or Iman Katolik, Buku Informasi dan Referensi (Catholic Faith. Information and Reference Book) of the Indonesian Bishops' Conference (1996). Stephen Bevans may put these efforts, books, and similar publications within the 'translation model' of contextual theology. The model, Bevans explains, "insists that there is 'something' that must be 'put into' other terms. There is always something from outside that must be made to fit inside; there is still something 'given' that must be 'received"' (Bevans, 2003, p. 39).

Second, there is another model, where theological issues are regarded as universal and addressed within the local context. The Sejarah Apostolat di Indonesia (The History of Apostolicity in Indonesia) of J.L. Ch. Abineno (1978) may represent this model. The articles "Indonesia-Dynamics for Creative Maturity" (Simatupang, 1976) and "Christian Faith in an Indonesian Environment" (Steenbrink, 2008), which deal with issues of ecclesiology and missiology with an ecumenical and historical emphasis, adopted a similar approach. This typology has a similarity to the 'praxis model' of Bevans' models of contextual theology, since "that theology is done not simply by providing relevant expression of Christian faith but also by a commitment to Christian action" (Bevans, 2003, p. 72).

While the book Compassionate and Free: An Asian Woman's Theology, written by Marianne Katoppo (1980), has a strong spirit of liberation. The writer explores the challenge of being Christian women in Asia, seeking the right to be different from the patriarchal culture's identities. To some extent, the spirit of liberation of this book goes together with other Asian feminists such as Kwok Pui-lan (Hong Kong) or Virginia Fabella (The Philippines) (Bavans, 2003, pp. 83-87).

Third, we can mention another model with its strong (ter)cultural, dialogical, and prophetical vitality. The works of Y.B. Mangunwijaya in his book Gereja Diaspora (The Church in Diaspora, 1999) or of A.B. Sinaga on Gereja dan Inkulturasi (The Church and Inculturation, 1984), to name just two books, could represent this model. I am convinced their works have a similar approach to 
Bevans' typology of 'synthetic model,' where "the creative and dynamic relationship between the Christian message and a culture or cultures" happens (Bevans, 2003, p. 90). To clarify the essence of this model, Bevans suggests another term, such as 'dialectical model,' 'dialogical model,' or 'conversation model.'

Highlighting these publications of the former generation are just a glim of various theological endeavors taken by the Christian communities, represented by their theologians. In the same spirit, our today's generation is without a doubt expected to carry on this enterprise and project in this new era. Our theological reflections that count seriously the context, namely the people's life, will contribute to the future of Christianity in the country. It is, first of all, the task of our Indonesian theologians. They are expected to intensify their theological reflection on the context (all aspects of life and experiences of the people: success and failure, birth and death, moments of tragedy, diseases, communal conflicts, etc.) in the light of the Christian faith. It is also the responsibility of each theological institutions or ecclesiastical faculties to review their theological education and training (Gravissimum Educationis, the Declaration on Christian Education, n. 11; Optatam Totius, the Decree on the Training of Priests, n. 17) for a better response to the challenge of our contemporary world.

\section{Toward the Maturity of the Church}

Wilfred's presentation at the conference has energized the participants to take more concrete steps in doing theology in our multi-cultural and multi-religious society for internal purposes (the church, theological institutes) and external concerns (the well-being of the country and its people). Since the context must be taken seriously, which means that all aspects of human life and experiences have to be incorporated, theology must closely collaborate with other disciplines. Interdisciplinary perspectives have been considered a must in energizing the life of the Church within the society. Such involvement and encounter will produce a more comprehensive reflection since sociological or anthropological perspectives, for instance, are seriously taken into theological considerations (Pilario, 2020). In other words, such collaboration will offer a more or less holistic view on human issues, and there will be a better response to the problems in context. Such interdisciplinarity will certainly have a great impact on our theological educations and their curricula as well.

\section{The Church and its Own Theology}

The term "the church with its theology" means the self-sufficient Church, the Church in its maturity. It is surely ironic if one says that Asian Church is still struggling to develop the so-called 'Asian theology', since Christianity in Asia has a very long history, even to the time of Jesus himself. Such a long story is very true in some parts of Asia, such as Western and Southern Asia. They have been there for generations, even with their way of doing theology. But in other parts of the continent, many Christian communities are quite new, even only one generation.

At this point we recall to Pope John Paul II when he gave a summary of the history of Asian Christianity in his Apostolic Exhortation 'Ecclesia in Asia' (EA) (John Paul II, 1999). We cite a few lines of his words: "[...] despite her centuries-long presence and her many apostolic endeavours, the Church in many places was still considered as foreign to Asia, and indeed was often associated in people's minds with the colonial powers" (EA, 9; cf. n. 21). And, although Jesus was born in an Asian soil (EA, 5), the fact is that he "is often perceived as foreign to Asia. It is paradoxical that most Asians tend to regard Jesus—born on Asian soil—as a Western rather than an Asian figure" (EA, 20). Meaning, 
there is still hard work for the Church in general and theologians and people serving in the Christian formation houses or institutions in particular.

There is a big challenge before us to do Christology or Ecclesiology or Pneumatology or even the Liturgy contextually. Despite that, the time has been mature enough for many observers to give to an authentic Asian theology. We fully agree with Felix Wilfred's position in his paper when he says that Asian Christians have begun to read the Bible and interpret their faith in their living context. There are plenty of books, articles, seminar papers, and the like that have become public consumption since the Second Vatican Council (1965). It might suffice here to mention few books compiling documents of the Federation of Asian Bishops' Conferences since its inception, which tell the Asian theological endeavour. Here are they: For All the Peoples of Asia, FABC Documents from 1970-1991, volume 1 (Manila: Claretian Publications, 1997) edited by Gaudencio Rosales and C.G. Arevalo; Volume 2: FABC Documents from 1992-1996 edited by Franz-Josef Eilers (Manila: Claretian Publications, 1997); Volume 3: FABC Documents from 1997 to 2001 edited by Franz-Josef Eilers (Manila: Claretian Publications, 2002); Volume 4: FABC Documents from 2002 to 2006 edited by Franz-Josef Eilers (Manila: Claretian Publications, 2007); and volume 5: FABC Documents from 2007 to 2012 edited by Tirimanna Vimal (Manila: Claretian Publications, 2014). There is also another book on FABC Documents entitled At the Side of the Multitudes, The Kingdom of God and the Mission of the Church in the FABC Documents (1970-1995) by Miguel Marcelo Quatra (Manila: Claretian Publications, 2000).

We are convinced that these publications came up from intense doctrinal and pastoral reflections on life experiences of our people. We need not extend the list of the documents of the local churches narrating the encounter of the gospel message and the life of the people. In short, the topics such as interfaith dialogues and interreligious collaborations of the Christians and the people from other religious communities (Hindus, Buddhists, Muslims, Confucians, etc.) are not new at all. The question then is: "How far have these encounters become integral parts of our theological curriculum and theological trainings?"

These small collections or documentations mentioned here may represent a lot more publications. They tell that Asian theology is very dynamic and grows contextually towards its maturity. Such theological enterprise surely expresses the self-awareness of being authentic Christian in Asian soil and within Asian soul. The Church has been struggling to become agent of theology in its particular ways. Minjung theology from Korea or Dalit theology from India, for example - that emerged in the 1970s and 1980s from the experience of the people struggling for justice - could represent the persistent venture of Christian communities in Asia who desire to speak for themselves and live their Christian faith obediently.

In his paper, Felix Wilfred also attracts our attention to the liberation movements in the various regions of Asia. We are informed of the experiences of the people who are struggling against colonial powers, repressive dictatorial regimes, all kinds of social and religious discrimination and political marginalization, as well as Asian women who are struggling to uphold their autonomy and freedom against patriarchy system, etc. However, Felix Wilfred explains that a Christian liberation theology is precisely the genuine response to this general mood of liberation.

It is time for the Church in Indonesia to grow towards maturity. From the reflection of the intensive meeting between the people's experiences in this country and the Christian message. A shift in context occurs in theology from the socio-cultural problems of Western society to real society's problems in Asia. 
Such a big change in context reminds to Walbert Bühlmann in his challenging books, such as, The Coming of the Third Church: An analysis of the present and future of the Church (Orbis Books, 1978); The Church of the Future: A model for the year 2001 (Orbis Books, 1986); or With Eyes to See: Church and world in the third millennium (Orbis Books, 1990). Bühlmann wrote: "The Second Church [of the West] will no longer find her true purpose in life primarily in herself but rather in setting up the conditions necessary for the life of the Third Church [of the Third World] in a hemisphere full of poverty and sickness, of non-Christian religions and seekers for truth" (Bühlmann, 1978). All these ideas and the related ones should be considered and incorporated into our formal theological education. They are integral parts of our theological themes in Asia.

The new interdependent and interconnected world of the post-colonial era has come, so the relationship of the Church of the West and the so-called 'young churches' takes a new form. People prefer to use partnership and mutual aid to describe their relationship to replace the former 'motherdaughter' one. The terms are valid not only in the area of financial or personnel but also in doing theology. We know that the Church of the West has been successful in its self-theologizing. Theology elaborated in the western world throughout the first and second millennium is contextual by nature. In its turn, in the third millennium, the Asian Church is mature enough to continue developing its way of doing theology based on the sources in Asian soil and soul. In principle, one can confirm this atmosphere, but there is still a lot of work to settle and accomplish in practice.

\section{The Asian context}

In this post-colonial era, Felix Wilfred explains that the new theological discourse emerges contextually by nature. The discourse is heavily characterized by a liberation tone, not explicitly the encounter of Asian Christians with people of other faiths. But, along with his presentation, we get a glimpse of the implicit impact of such encounters. Such as how to deal properly with the mission, theology of religions, and globalization impacts. Of course, we have been trying to cope with such issues in our theological endeavor. We have been struggling to elaborate a Christology or Pneumatology or the mystery of the Trinity in Asian spirit. But there is still a lot of work to do.

In other words, since doing Asian theology takes roots in Asian soil, our Asian systematic theology has to be developed consistently to a degree of recognition as a dialogue partner for other contextual theologies elaborated in other continents. How far can Asian Church go forward in dealing with Asian creative theology, instead of merely translating as faithfully as possible Christian theology once formulated sophisticatedly in the West?

We also develop terms such as 'Asian-ness,' 'being Asian,' and the like. Since the inception of FABC in the early 1970s, we have been familiar with the three dimensions which characterize the Asian context: the poor, the cultures, and the great religions of Asia. In these three dimensions, various Asian theological questions could arise. To our mind, then, comes up the former three-fold dialogue promoted and elaborated by the Federation of Asian Bishops' Conference. The three-fold dialogues were announced by the First FABC General Assembly in Taipei (1974) and later on have become programmatic for the development in thought and pastoral orientations of FABC. Asian Christians have gone to fides quaerens dialogum, not just fides quaerens intellectum. In the last couple of years, the dialogue has been extended into four-fold one, including the concern of the church in dealing with the crisis of ecology. These four distinctive features of Asia are certain parts of our theological consideration. 
As far as we think on theological education, the question that should be raised: "How far these four Asian characteristics have been taken as integral parts of our theological curricula?" we are reminded that dialogue with Asian poverty, with Asian cultural diversity, with Asian religions, with the ecological crisis in Asia, is of great importance for the construction of our authentic theology. Furthermore, issues on migrant workers, gender justice, child labor, human trafficking, neo-colonialism, urbanization, etc.; minority rights, ethnic conflicts, globalization, etc.; religions of Asian origin as well as imported ones, religious fundamentalism, the revival of many sects, issues on the spirit world, etc.; and deforestation, natural disasters, diseases, the disappearance of many species, etc. could not be neglected as well in our theological reflection.

I am convinced that theology in the Indonesian context should take these four characteristics seriously in our theological educations and training. We can no longer be neglecting these issues or treating them just as pastoral issues with their possible pastoral solutions. In other words, we should find models to deal with them so that more systematic theology can be worked out. This is precisely the task that we should carry out as an important point in our theological agenda. Certainly, we have the consent to go forward in doing theology as a close collaboration with other related disciplines, both for the construction of our systematic theology and the church's mission in the world (applied theology).

About 'being Asian,' a distinctive feature we have fully recognized is that Christianity has always existed alongside other major world religions and plenty of religious traditions (Thomson, 2008), and mostly Christian communities are small flock spread all over the continent with an exception the church in the Philippines. It means that Asian Christians have been conditioned to grow in an atmosphere of religious pluralism and the spirit of mutual respect with people of other faith traditions. Pilario asserts that "the culture of dialogue as a constant in the traditions, philosophies, literature, and culture in Asia can never be exaggerated" (Pilario, 2020). Dialogue, complementarity, and harmonies are integral aspects and particularities of 'being Asian' with its logic of 'both-and' instead of 'either-or' one. FABC Office of Theological Concerns underlines the value of pluralism as a theological method in an Asian context that should critically be regarded as enrichment (FABC, 2000, pp. 4-10). In his Apostolic Exhortation Ecclesia in Asia, Pope John Paul II mentions this character of Asianness in the following lines: "This 'being Asian' is best discovered and affirmed not in confrontation and opposition, but the spirit of complementarity and harmony. In this framework of complementarity and harmony, the church can communicate the Gospel in a way which is faithful both to her tradition and to the Asian soul" (EA, $6)$.

To this point, we arrive at the consent that doing theology in an Asian context is part of our theological formation. Therefore, all these characteristics of Asianness and the related themes should be incorporated into our theological curricula. The questions, then, would be: "How seriously do we take such responsibility of doing theology (as Asians) in the Asian context? How serious are we to incorporate the four-fold dialogue in our theological curricula? Do we have any courage, for example, to reconstruct our theological education and training based on the four-fold dialogue? What about Asian issues such as 'the spirit world' or 'ancestor worship'? Do they have any place in our theological formation to be addressed systematically?"

\section{What makes Asian theology really 'Asian'?}

Now we come to the question of 'what makes Asian theology Asian?' Felix Wilfred proposes, I believe, the public character of Asian theology (Wilfred, 2019). He offers a well-elaborated process of doing 
theology, which challenges our traditional theological pursuit. Instead of being scientific, today's theology acquires public character, relates itself to the reality of public life, and asks what contributions it could make. Public theology, Wilfred asserts, is a new genre in theology. It is different from theology for public life as well as the traditional one. It is different from theology for public life since "the concrete life-situation and the questions emanating from it are taken seriously, and an effort is made to respond to them in faith - a faith that understands itself in relation with others and not as a private matter." Public theological reflection in the Asian context should begin from the world and needs to be open-ended for its responsibility to the larger world. Traditional theology, on the other hand, Wilfred emphasizes, "tends to cut everything - the world, society, and culture - to its size, reminding us of the Procrustean bed!' (Wilfred, 2019). This way of pursuing theology could have great repercussions on rethinking its methods and sources.

All this reminds me again of the Apostolic Exhortation Evangelii Gaudium (EG) of Pope Francis on 'a church which goes forth' mentioned above, which is of self-critique for all Christian communities. Like Abraham, Moses, Jeremiah, or Jesus' disciples were sent out to be a blessing for humanity. The Asian Church is sent to involve in its surrounding within the larger society and contribute to the common good and the well-being of all. The Pontiff also says:

In our day, Jesus' command to 'go and make disciples' echoes in the changing scenarios and ever new challenges to the Church's mission of evangelization, and all of us are called to take part in this new missionary 'going forth.' Each Christian and every community must discern the path that the Lord points out, but all of us are asked to obey his call to go forth from our comfort zone to reach all the 'peripheries' in need of the light of the Gospel. (EG, 20)

We could also add the issues mentioned above, namely the spirit world of most Asian minds or Asian religious tradition. I suppose we cannot treat it as merely a pastoral issue but also must be thought through theologically. In dealing with it theologically, the church has surely presented itself as an integral part of Asian communities. Asian theology is not merely elaborated by Asian Christian as the agents of theology or developed upon Asian soil, but touch the core of the Asian soul searching for a fuller life.

From the rich Asian religiosity, the Asian Church inherits plenty of spiritual insight and moral wisdom. John Paul II enlists those spiritual insights and moral wisdom as follows:

[...] love of silence and contemplation, simplicity, harmony, detachment, non-violence, the spirit of hard work, discipline, frugal living, the thirst for learning and philosophical inquiry; respect for life, compassion for all beings, closeness to nature, filial piety towards parents, elders, and ancestors, and a highly developed sense of community; family as a vital source of strength, a closely-knit community with a powerful sense of solidarity; the spirit of religious tolerance and peaceful co-existence; the capacity for accommodation and a natural openness to the mutual enrichment of peoples amid a plurality of religions and cultures; etc. (n. 6).

On the other hand, the Asian Church is called and sent to be blessings for others and society. To accomplish its mission, the Pontiff says that the same spirit also drives the Holy Spirit, who moved upon Asia in the time of the patriarchs and prophets, the church of today to carry out its part for the full realization of God's Kingdom (EA, 17) (John Paul II, 1990). The Holy Father continues: "The Spirit reminds the Church that she is not an end unto herself: in all that she is and all that she does, she exists to serve Christ and the salvation of the world" (EA, 17). This pastoral encouragement echoes God's message once entrusted to Abraham when God convinces him, saying: I will make you into a great nation, and I will bless you; I will make your name great, and you will be a blessing. I will bless those 
who bless you, and whoever curses you I will curse, and all peoples on earth will be blessed through you. (Genesis 12:2-3 [NIV]).

In mentioning all this, I would like to emphasize that it is fundamental to comprehend precisely the identity of the Asian Church, namely being a participant in God's grand design for the salvation of humanity. Asian Church and its theology must be of great contribution to humanity's well-being and be a blessing for society. The contrary would also be true. Any theology or religion that dehumanizes humanity must include a false theology or religion.

\section{Concluding Remarks: Our Agenda}

We have fully understood that theology is no longer comprehended merely as a depositum fidei (deposit of faith), a body of knowledge or doctrines to be faithfully handed down from generation to generation, from the West to the other parts of the globe with great care and concern. On the contrary, public theology must start from the life experiences of the people and respond to them in faith. We understand that public theology takes seriously human experiences, social locations, cultures, and social changes. With its bottom-up method, the people of Asia's concrete experiences can be read dialectically with the Scripture and Christian tradition.

Now we put our plan as follows: "How serious are we in dealing with our Asian experiences, Asian world-views, and world events as the very sources of our theological enterprise, in dialogue with the Scriptures and tradition and incorporated them into our theological curricula? How is the interdisciplinary character of our Asian way of doing theology demonstrated in our theological education and training? How far do we promote a critical engagement or a prophetic dialogue with local cultures, local genius, and ecological issues for the preservation and sustenance of life?" No doubt, our theological endeavors should promote a responsive engagement with the diverse Asian contexts mutatis mutandis Indonesian ones.

Our way of doing theology in context must arrive at the position of being recognized as partner dialogue with other ways of doing theology in other parts of the globe, particularly with the West's Church. We recognize that there are various ways of doing theology that depend on the actual context and theology agents. It is timely for the Asian Church to focus on its rights and responsibility as an agent of credible theology. Guided by the Holy Spirit, Asian Church should be convinced of being able to develop credible Asian theology from our Asian soul of harmony, wholeness, less institutional, respect difference. We envision a world Church that accommodates a dialogical atmosphere. The aim was for contextual theology developed in different local churches. It can be promoted by the Federation of Bishops' Conferences on every continent. Thus, the world Church has become catholicos, universal, and community in its true sense. We are dreaming of the world Church that accommodates a dialogical for contextual theologies developed in different local churches. They were promoted by the Federation of Bishops' Conferences in each continent. In so doing, the world Church has become catholicos, universal, and community of communities in a real sense.

\section{References}

Abineno, J.L. Ch. (1978). Sejarah Apostolat di Indonesia (2 vols.). Jakarta: BPK Gunung Mulia. Aritonang, Jan Sihar and Karel Steenbrink. eds. (2008). A History of Christianity in Indonesia. Leiden-Boston: Brill. 
Bevans, Stephen B. (2003). Models of Contextual Theology (Revised and expended edition). Manila: Logos Publications.

Bühlmann, Walbert. (1978). The Coming of the Third Church: An analysis of the present and future of the Church. New York: Orbis Books.

England, John C., Jose Kuttianimattathil, John M. Prior, Lily A. Quintos, David Suh Kwang-sun, and Janice Wickeri. Eds. (2002) Asian Christian Theologies. A Research Guide to Authors, Movement, Source. Volume 1: Asia Region, South Asia, Austral Asia. New York: Orbis Books.

England, John C. et al. (2003). Asian Christian Theologies. A Research Guide to Authors, Movement, Source. Volume 2: Southeast Asia. New York: Orbis Books.

England, John C. et al., Asian Christian Theologies. A Research Guide to Authors, Movement, Source. Volume 3: Northeast Asia, New York: Orbis Books, 2004.

FABC Office of Theological Concerns. (2000). Methodology: Asian Christian Theology Doing Theology in Asia Today. FABC Papers No. 96. Hong Kong, October.

Francis. (2013). Apostolic Exhortation Evangelii Gaudium. Vatican. November 24.

Hadiwijono, Harun. (1992). Iman Kristen. Jakarta: BPK Gunung Mulia.

Hiebert, Paul G. (1985). Anthropological Insights for Missionaries. Michigan: Baker Academic.

John Paul II. (1990). Encyclical letter Redemptoris Missio. On the permanent validity of the Church's missionary mandate. Vatican. December 7.

(1999). Post-Synodal Apostolic Exhortation Ecclesia in Asia. Vatican, November 6.

Katoppo, Marianne. (1980). Compassionate and Free: An Asian Woman's Theology. New York: Orbis Books.

Mangunwijaya, Y.B. (1986) Ragawidya. Religiositas Hal-hal Sehari-hari. Yogyakarta: Kanisus.

Mangunwijaya, Y.B. (1999) Gereja Diaspora. Yogyakarta: Kanisius.

Muskens, M.P.M. et al. (1972). Sejarah Gereja Katolik Indonesia (4 volumes), Ende: Percetakan Arnoldus.

Muskens, M.P.M. (1979). Partner in Nation Building: The Catholic Church in Indonesia. Aachen: Mission Aktuell Verlag.

Pilario, Daniel Franklin E. (2020). "Interdisciplinary Perspectives and Approaches in Theologizing in Asia." in International Journal of Indonesian Philosophy \& Theology. Vol 1 (1).

Rosariyanto, F. Hasto. ed. (2001). Bercermin pada Wajah-wajah Keuskupan Gereja Katolik Indonesia. Yogyakarta: Kanisius.

Simatupang, T.B. (1976) "Indonesia - Dynamics for Creative Maturity," in G.H. Anderson (ed.). Asian Voices in Christian Theology. New York: Orbis Books.

Sinaga, Anicetus B. (1984). Gereja dan Inkulturasi. Yogyakarta: Kanisius.

Steenbrink, K.A. (1973). "Christian Faith in an Indonesian Environment." Exchange 5 (1973).

Suharyo, Kardinal Ignatius. (2020). "Teologi Publik.” in Robert Pius Manik, Gregorius Pasi, Yustinus (eds.). Berteologi Baru untuk Indonesia. Yogyakarta: Kanisius, 155-158.

Thompson, David M. (2008). "Introduction: mapping Asian Christianity in the context of world Christianity," in Sebastian C. H. Kim, ed. Christian Theology in Asia. Cambridge: Cambridge University Press, 3-21. 
Vatican Council II. (1984). Ad Gentes, the Decree on the Church's Missionary Activity, in Austin Flannery (ed.). Vatican Council II: The Conciliar and Post Conciliar Documents. Vol 1. Collegeville. MN: Liturgical Press.

Vatican Council II. (1984). Gravissimum Educationis, the Declaration on Christian Education. in Austin Flannery (ed.), Vatican Council II: The Conciliar and Post Conciliar Documents. Vol 1. Collegeville. MN: Liturgical Press.

Vatican Council II. (1984). Optatam Totius, the Decree on the Training of Priests. in Austin Flannery (ed.). Vatican Council II: The Conciliar and Post Conciliar Documents. Vol 1. Collegeville. MN: Liturgical Press.

Wilfred, Felix. (2019). “Asian Theological Ferment.” Keynote Address of the International Joint Conference. Yogyakarta, March 1. 